\title{
Diş Hekimliği Pratiğinde Rubber Dam ve Uygulama Yöntemleri
}

\author{
Mehmet Eskibağlar(0000-0003-0183-3824) ${ }^{\alpha}$, Büşra Karaağaç Eskibağlar(0000-0003-0775-9274) ${ }^{\beta}$, \\ Mustafa Gündoğar(0000-0001-8656-7101) ${ }^{\mathrm{y}}$, Taha Özyürek(0000-0003-3299-3361) ${ }^{\delta}$
}

Selcuk Dent J, 2021; 8: 875-880 (Doi: 10.15311/selcukdentj.755821)

Başvuru Tarihi: 22 Haziran 2020 Yayına Kabul Tarihi: 07 Ekim 2020

\begin{abstract}
öz
Diş Hekimliği Pratiğinde Rubber Dam ve Uygulama Yöntemleri

Diş hekimliği uygulamalarının çoğunluğunda izolasyon işlemi gereklidir. Bu işlem için sıklıkla rubber dam yöntemi tercih edilir. Rubber dam çalışma alanının uygun bir şekilde izolasyonunu sağlayarak işlemin başarısını arttıır. Bunun yanı sıra aerasol oluşumunu azaltır. Günümüzde özellikle damlacık yoluyla bulaşan koronavirüs gibi enfeksiyöz hastalıklara karşı hasta, hekim ve hekim yardımcılarını korur. Çalışma alanını optimal hale getirerek hekimin görüşünü arttırır ve olası ağız içi yumuşak doku yaralanmalarının önüne geçer. Bu makalede diş hekimliğinde sıklıkla kullanılan rubber dam izolasyon yöntemi anlatılmaktadır.
\end{abstract}

\section{ANAHTAR KELIMELER}

Diş hekimliği, İzolasyon, Rubber dam

Diş hekimliği uygulamalarında başarıya ulaşmak için çalışma alanının izole edilmesi büyük önem taşımaktadır. ${ }^{1-4}$ Çalışma alanının izolasyonunda; etkinlikleri farklı seviyelerde olmakla birlikte, pamuk rulo, otomaton, tükürük emiciler, retraksiyon ipleri ve rubber dam veya bunların kombinasyonları kullanılabilir. ${ }^{5-7}$

Çalışma alanının izolasyonunda hedef; tükürük, diş eti oluğu sıvısı ve diş eti kaynaklı kanamalardan korumak aynı zamanda diş eti, dil, dudak, yanak gibi dokuları ekarte ederek çalışma alanını çevre dokulardan uzaklaştırmaktır. ${ }^{8-11}$

Diş hekimliğinde çeşitli izolasyon yöntemlerinden en çok tavsiye edilen yöntem rubber dam ile izolasyon yöntemidir. ${ }^{3,4,11-16}$

\section{Rubber Dam}

Rubber dam, 15 Mart 1864 yilında Dr. Sanford C. Barnum tarafından diş hekimliğinde kullanııması amacıyla geliştirilmiştir. ${ }^{17,18}$ Dişlerin izolasyonunda yaklaşık 150 yıldan fazla süreyle kullanılmaktadır. ${ }^{4}$ Avrupa Endodonti Birliğinin 2006 yılında yayınlamış olduğu kılavuzda kök kanal tedavisinin tüm aşamalarının rubber dam izolasyonu kullanılarak yapılması gerektiğini belirtmiştir. ${ }^{14}$ Amerikan Endodontistler Derneğinin 2010 yılındaki bildirisinde cerrahi olmayan endodontik tedavilerde rubber dam kullanılması önerilmiştir. ${ }^{19}$

\footnotetext{
${ }^{\alpha}$ Fırat Üniversitesi Diş Hekimliği Fakültesi, Endodonti AD, Elazığ, Türkiye

$\beta$ Fırat Üniversitesi Diş Hekimliği Fakültesi, Çocuk Diş Hekimliği AD, Elazı̆̆, Türkiye

${ }^{v}$ İstanbul Medipol Üniversitesi Diş Hekimliği Fakültesi, Endodonti AD, İstanbul, Türkiye

$\delta$ İstanbul Bahçeşehir Üniversitesi Diş Hekimliği Fakültesi, Endodonti AD, İstanbul, Türkiye
}

\section{ABSTRACT}

\section{Rubber Dam and Application Methods in Dental Practice}

Isolation is necessary in most dental practices. Rubber dam method is often preferred for this process. Rubber dam improves the success of the process by providing proper isolation of the study area. In addition, it reduces aerosol formation. Today, it protects of the operator and the dental staff and the patients from infectious diseases such as coronavirus transmitted by droplets. By optimizing the way it works, it prevents possible soft mouth tissue injuries that you choose from the operator's view. In this review article, rubber dam isolation method which is used frequently in dentistry is explained.

\section{KEYWORDS}

Dentistry, Isolation, Rubber dam

Rubber Dam Kullanımının Avantajları 1-20

1- Rubber dam, uygun şekilde yerleştirildiğinde, dişi herhangi bir prosedürü bozabilecek engellerden (tükürük, dil, dudaklar ve yanaklar) izole ederek tedaviyi kolaylaştırır.

2- Kök kanal tedavisi sırasında kullanılan el veya döner aletlerin, irrigasyon solüsyonlarının, restoratif materyallerin aspirasyonunu veya yutulmasını önler.

3- Aerasol oluşturan işlemlerde, su hastanın ağız ortamı yerine lastik örtüye temas ettiği için, çapraz enfeksiyona karşı koruma sağlar ve enfeksiyonun potansiyel yayııımını engeller.

4- Dişeti, dil, dudak, yanak gibi yumuşak dokularda oluşabilecek kazalara karşı koruma sağlar.

5- Kuru bir çalışma alanı oluşturduğu için aynada buğu oluşumunu engeller, görüş alanını artırır. Loop ve mikroskop gibi büyütme ve aydınlatma sistemlerinde odaklanmayı kolaylaştırır.

6- Kullanılan materyallerin tükürük veya diğer ağız sıvıları ile temas ederek fiziksel ve mekanik özelliklerinin bozulmasını önler.

7- Hastada konuşma, tükürme, ağzını kapatma gibi durumları engelleyerek tedavi süresi kısaltılır ve çalışma alanının kontaminasyonu engellenir. 
8- Kullanılan aletlerin oral mukozada hassas noktalara örneğin palatinal mukozaya temas ederek hastada bulantı refleksi oluşmasını engeller.

\section{Rubber Dam Parçaları:}

Rubber dam temel olarak 5 parçadan oluşmaktadır. Bunlar; lastik örtü, çerçeve, klemp, forseps, lastik örtü delicidir.

\section{Lastik Örtü:}

Çoğu firmalar, çeşitli uygulamalar için farklı boyut, kalınlık ve renklerde lastik örtü üretmektedir.

Boyut olarak tekli $12,5 \times 12,5 \mathrm{~cm}, 15 \times 15 \mathrm{~cm}$ olarak, rulolar halinde $15 X 55 \mathrm{~cm}$ boyutlarında olabildikleri gibi çerçeve ile birlikte olan lastik örtüler de mevcuttur. Bazı lastik örtülerde delik yerleri belirlenmiştir.

Kalınlıklarına göre ince $(0,15 \mathrm{~mm})$, orta $(0,20 \mathrm{~mm})$, kalın $(0,25 \mathrm{~mm})$, ekstra kalın $(0,30 \mathrm{~mm})$, özel kalın (0,35 mm) olabilirler. İnce rubber dam örtüleri, dişlerin interproximal alanlarından daha kolay geçebildikleri için sıkı kontak yapısına sahip hastalarda daha rahat kullanılabilir. Fakat ince yapısından dolayı manüplasyon esnasında yırtılabilirler. Kalın yapıdaki lastik örtüler dokuları daha etkili bir şekilde ekarte eder ve yırtılmaya karşı daha dirençlidir, fakat çerçeve ve klempe daha fazla kuvvet uygularlar. Bu yapısından kaynaklı servikal bölgede gerçekleştirilmesi planlanan restorasyonlarda kullanılabilirler. Posterior dişlerde ince örtülerin, anterior dişlerde ise kalın örtülerin kullanımı önerilmekle beraber, orta kalınlıktaki örtüler ağız içerisinde tüm bölgelerde kullanılabilir. 6,7,13,16,21,22

Rubber dam örtüleri siyah, mavi, yeşil, pembe gibi çeşitli renklerde üretilmektedir. Koyu renkli lastik örtüler kontrast oluşturmak için kullanılır. Operasyon mikroskobu kullanıldığı durumlarda koyu renk lastik örtünün seçilmesi çalışma alanına odaklanmayı kolaylaştırır. ${ }^{16}$ Lastik örtülerin yüzeyi bir taraf parlak diğer taraf mat olacak şekilde tasarlanmıştır. Mat taraf ışığı daha az yansıttığı için, izole edilecek diş veya dişlerin oklüzal tarafına gelmesi önerilmektedir. Dişin renk analizinin gerektiği durumlarda izolasyon işlemi renk analizinden sonra yapılmalıdır. ${ }^{6}$

Lastik örtüler genellikle lateks lastiğinden üretilir. Uygulama öncesi, hastada lateks alerjisi sorgulanmalı, lateks alerjisi olan hastalarda lateks içermeyen örtüler kullanılmalıdır. Lateks içermeyen örtüler düşük elastisiteye sahip olduğu için daha küçük bir delik açılmalıdır. ${ }^{16}$ Bu örtüler kauçuk kokusunun giderilmesi için nane, vanilya gibi kokular içerebilir.

Birçok dental materyalde olduğu gibi lastik örtülerinde kullanım ömrü vardır. Bu örtülerin zamanla yırtılmaya karşı dirençleri azalır, bu nedenle üretim tarihi yakın olan lastik örtüler kullanılmalıdır.

\section{Çerçeve:}

Klemp ile diş üzerine yerleştirilip, sabit hale getirilen lastik örtünün gergin bir şekilde stabil durmasını ve dil, dudak ve yanakların ekarte edilmesinde kullanılır.

Rubber dam çerçeveleri $U$ şeklinde veya oval formlarda olabilir. Bu çerçeveler metal veya plastikten üretilirler (Resim 1-2). Plastik çerçeveler metal çerçevelere oranla daha kalın bir yapıya sahiptir. Ancak metal çerçeveler plastik çerçevelere göre daha dayanıklıdırlar. Metal çerçeveler radyografi alınması sırasında görüntü üzerine süperpoze olabilirler. Bu nedenle radyografi alınırken çıkarılmalıdır. Ancak plastik çerçeveler radyografi alındığında görüntü üzerine süperpoze olmazlar. Aynı zamanda bazı plastik çerçeveler radyograf alınmasını kolaylaştırmak için menteşeli üretilebilmektedir (Resim 3). 6,13,16,24
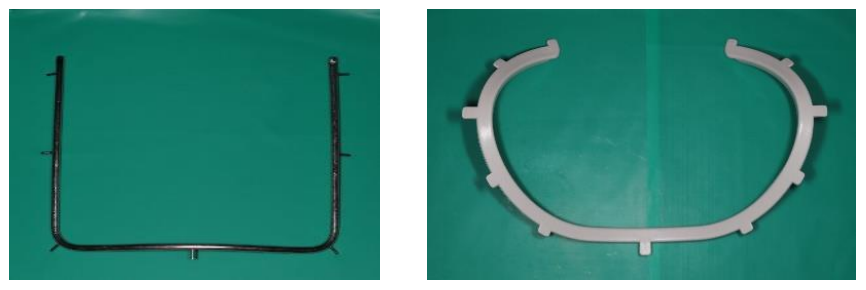

Resim 1-2

Metal Çerçeve ve plastik çerçeve

Klemp:

Lastik örtünün dişin kole bölgesine tam olarak oturmasını ve oklüzal yöne hareketini engellemek için kullanılırlar. Klempler genel olarak ağız, ark, delik, sivri uç, kanat kısımlarından oluşur (Resim 3). Klemp seçimi yapılırken, dişin ekvator hattının kavsi, kole çapı, diş dokularındaki kayıp, dişin arkta sürme miktarı değerlendirilmelidir. Lastik örtünün başarılı bir retansiyonunun sağlanabilmesi için klempin dişe ideal bir şekilde yerleştirilmesi gereklidir. İdeal yerleştirilen klemp dişe dört noktada temas etmeli ve klempin ark kısmına parmakla basıldığında hareket etmemelidir. 6,13,16,21

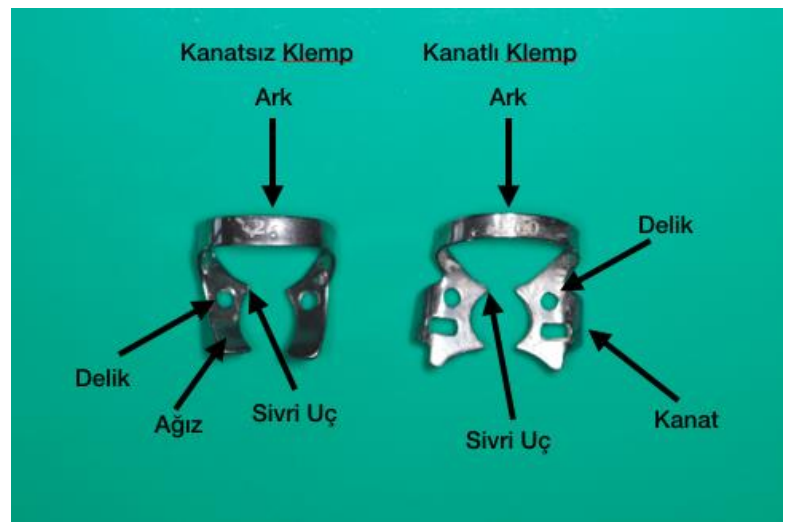

Resim 3

Kanatsız ve kanatlı klemp bölümleri 
Klempler metal veya plastikten, çeşitli büyüklük, form ve renklerde imal edilirler. Üreticiler tarafından kanatı/kanatsız, maksiller/mandibular, anterior/posterior ve premolar/molar klempleri gibi çok çeşitli klemp tipleri bulunmaktadır (Resim 4). ${ }^{25}$

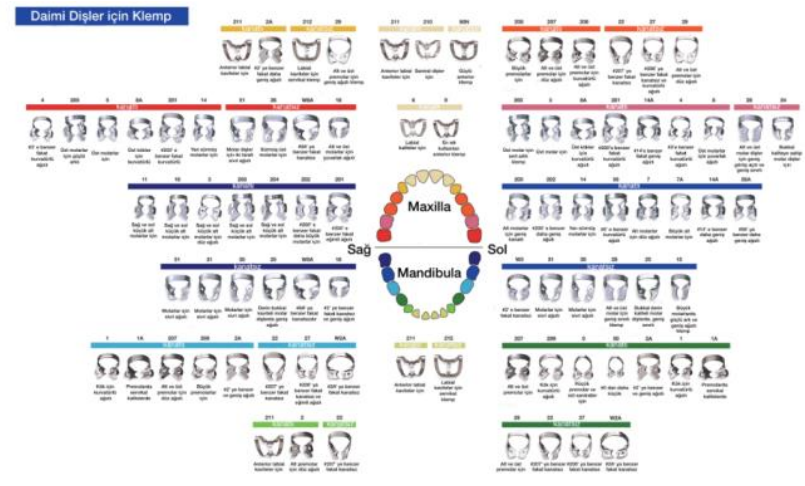

Resim 4

Farklı klemplerin kullanım yerlerini içeren şema. ${ }^{25}$

Klemplerin kırılıp yutulmasını ve aspirasyonunu önlemek için; bir diş ipi klempin her iki kolundan bağlanarak dışarı alınmalı veya çerçeveye bağlanmalıdır. ${ }^{6,16,21}$

Forseps:

Forsepsler uç dizaynları birbirinden farklı olarak üç ayrı şekilde tasarlanmıştır. Bunlar washington, brewer ve ivorydir. Forseps klempleri yerleştirmek için özel yapılmış sivri ve uzun uçları bulunan bir penstir (Resim 5). Klempin dişin kole bölgesi üzerine yerleştirilmesi ve işlem sonrasında da çıkarılması için kullanılır. Forsepsin çıkıntılı ucu klempin iki deliğine geçirilerek sıkılır, klempin açıması sağlanır. Klemp uygun pozisyona getirildikten sonra forseps gevşetilerek ağızdan çıkartılır. Forsepsin kelepçesi ayarlandığı zaman sabit durmalıdır eğer kelepçede herhangi bir problem meydana gelirse klemp forsepsten ayrılabilir, hastanın klempi aspire etmesine veya yutmasına sebep olabilir. ${ }^{13,21,24}$

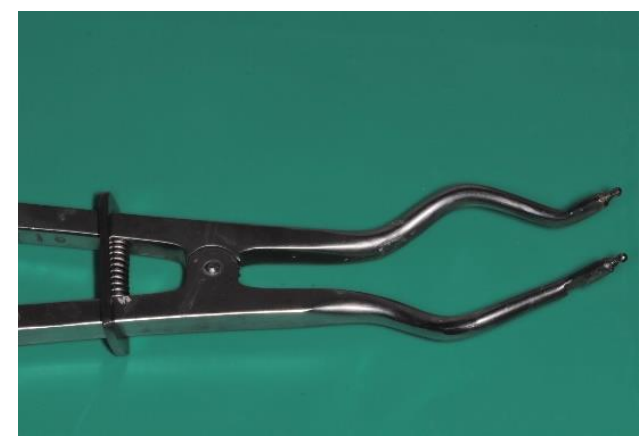

Resim 5

Forseps.

Delici:

Lastik örtüler üzerinde, işlem yapılacak bölgedeki izole edilmesi planlanan diş veya dişlerin kole çaplarına uygun delikler hazırlamak için kullanılan bir alettir. Tek delikli, ivory ve ainswoth's olarak üç farklı delici çeşidi vardır. Bunlardan günümüzde en sık kullanılan ainswoth's delicidir. Uca doğru konikleşen sivri uçlu ve metal döner tablaya sahip bir yapısı vardır (Resim 6-7). Üzerinde en küçüğü 0.7 mm, en büyüğü $2 \mathrm{~mm}$ çapına sahip beş veya altı delik bulunur. Sivri uç karşılığındaki deliğe tam oturmalıdır. Delikler, yuvarlak ve düzgün bir şekilde tek hamlede açılmalıdır, aksi halde yerleştirme esnasında lastik örtüde yırtılma meydana gelebilir. ${ }^{6,13,16,24}$
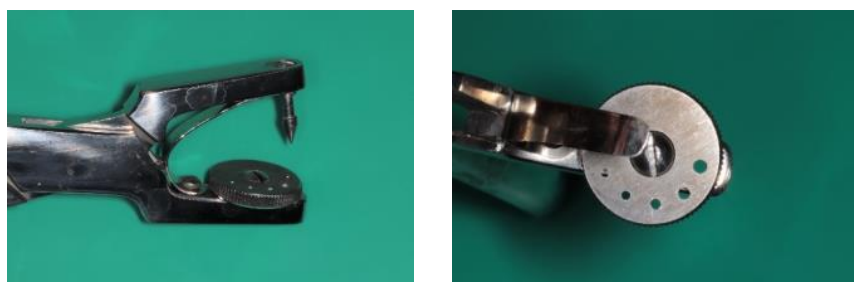

Resim 6-7

Delici

Rubber Dam Uygulanmasında Kullanılan Yardımcı Malzemeler

\section{Lubrikantlar}

Sıkı kontaklı dişlerde lastik örtünün daha rahat geçmesi için kullanılan malzemelerdir. Bu amaçla ticari firmaların ürünleri kullanılabileceği gibi vazelin, topikal anestezik jel, koka yağı, traş kremi de kullanılabilir. ${ }^{13,21,24,26}$

Diş İpi

Klemp yerleştirildikten sonra, diş ipi, klempler üzerindeki delikten geçirilerek yüz çerçevesine bağlanır. Böylece klempin kırılma veya yerinden çıkması sonucu aspire edilmesi veya yutulmasının önüne geçilir. ${ }^{13,21,24}$ Diş ipi, sıkı kontaktaki dişlerde lastik örtünün kontak bölgesinden geçirilerek kole bölgesine ilerletilmesine yardımcı olur. Ayrıca diş etinin daha apikale itilmesi gereken bazı vakalarda diş ipi üzerine düğüm atılarak lastik örtünün sabitlenmesi ve apikale ilerletilmesi sağlanabilir.

\section{Lastik Örtü Yastığı}

Lastik örtüyle yüz bölgesi arasına yerleştirilen Sıvı emici malzemelerdir. Lastik örtüden kaynaklı terleme, alerjik reaksiyonlar ve tükrüğün dudak kenarlarından sızmasını engellemek amacıyla kullanılırlar. İzolasyon için bir önemi yoktur. Kağıt havlular veya peçeteler bu amaçla kullanılabilir. ${ }^{13,21}$

\section{Yardımcı İzolasyon Maddeleri}

Rubber damın yerleştirilmesi sonrası ağız ortamıyla ilişkide olan bölgelerde oluşabilecek sızıntılar, açık kök kanalının kontamine olmasına sebep olabilir. Yardımcı izolasyon maddeleri sızıntıları önlemek amaçlı klemp ile dişin arasındaki boşlukları kapatmak için kullanılan rezin veya silikon esaslı malzemelerdir. ${ }^{13,21,24}$ 


\section{Rubber Dam Klinik Uygulaması}

\section{Ön Hazırlık:}

Lastik örtü uygulamasından önce izole edilecek bölgenin kontrol edilmesi ve uygulamaya engel durumlar mevcutsa bu durumların ortadan kaldırıması gereklidir. Restorasyonlar radyografik ve klinik olarak kontrol edilmelidir. Diște aşırı madde kaybı, yetersiz kontur, uygun olmayan restorasyonların varlığı, diş taşları bulunması gibi durumlarda bu durumların elimine edilmesi gereklidir. Klemp sağlam dokular veya restorasyonlara takılmalıdır. Klemp genellikle işlem yapılacak dişe takılır fakat dişte klemp tutuculuğunu etkileyecek durumlar varsa birden fazla dişi içerecek şekilde uygulama yapılabilir.

\section{Lastik Örtünün Delinmesi}

Lastik örtüde delme işlemi yapılırken deliğin, lastik örtünün tüm ağzı kaplayacağı şekilde ve burna kadar uzanabileceği bir konumda olmasına özen gösterilmelidir. $\mathrm{Bu}$ konumun belirlenmesinde genellikle lastik örtülerle beraber diş ark rehberinin yer aldığı delik işaretlemelerini içeren şablonlar ve deliklerin belirtildiği lastik örtülerde bulunmaktadır (Resim 8). Ayrıca lastik örtü çerçeveye geçirilip ilgili dişe doğru itilerek lastik örtüde oluşan izden ya da lastik örtü işaretlenerek delme işlemi yapılabilir (Resim 9-10).

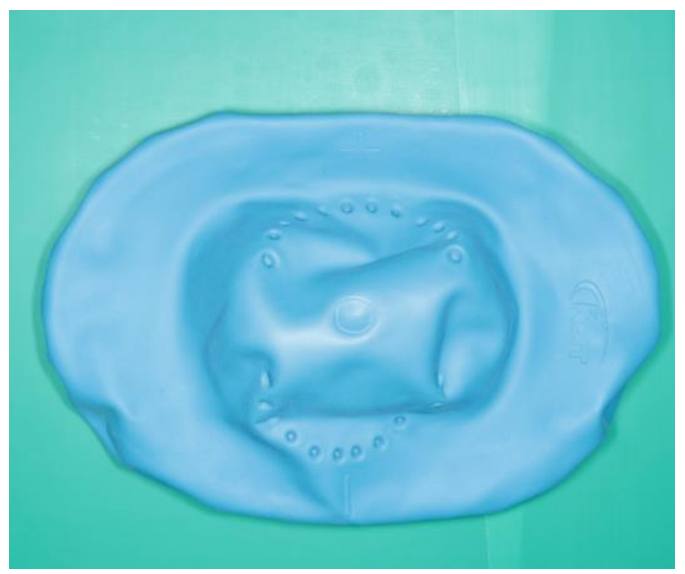

Resim 8

Deliklerin belirli olduğu lastik örtü.
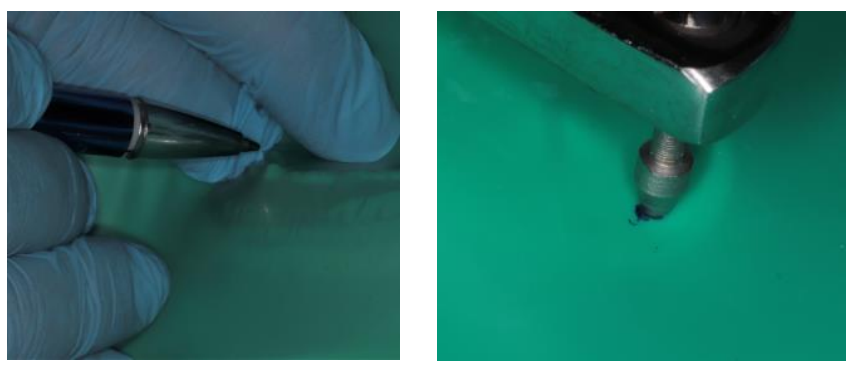

Resim 9-10

Lastik örtünün işaretlenmesi ve delinmesi

\section{Lastik Örtünün Uygulanması}

Lastik örtünün dişe uygulanmasında 4 yöntem mevcuttur.

\section{Yöntem}

$\mathrm{Bu}$ yöntemde lastik örtü, klemp ve çerçeve ağız dışında hazırlanır ve tek parça halinde dişe yerleştirilir. Lastik örtünün delinmesi işleminden sonra, çerçevenin iç bükey kısmı hastanın yüzüne bakarken, çerçevenin açık kenarı hastanın burnuna bakacak şekilde ayarlanır. Lastik örtü gergin olmayacak şekilde çerçevenin çıkıntılı kenarlarına yerleştirilir. Klempin kanatları lastik örtünün altında kalacak şekilde takılır ve klemp forsepsle dişe taşınır. Lastik örtü, çerçeve ve klemp bir ünite halinde dişe yerleştirilir. Forseps uzaklaştıııır. Lastiğin kenarları klempin kanatlarından bir ağız spatülü yardımıyla kurtarılarak dişin kole bölgesini sarması sağlanır (Resim 11A, B, C, D).
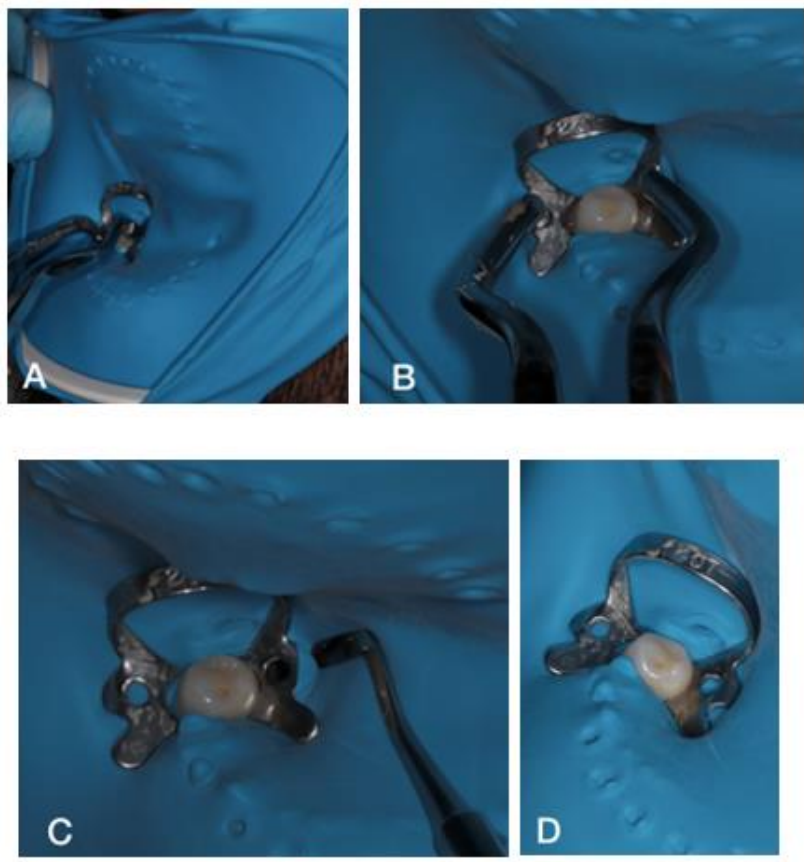

Resim 11

A. Rubber damın ağız içerisine taşınması. B. Klempin dişe yerleştirilmesi. C. Ağız spatülü yardımıyla lastiğin kole bölgesine ayarlanması. D. Klempin ve lastik örtünün kontrolü.

\section{Yöntem}

Klempin dişe yerleştirilmesinden sonra, lastik örtü ve çerçevenin birlikte yerleştirildiği yöntemdir. Öncelikle dişe uygun klemp seçilir ve forseps yardımıyla klemp dişe yerleştirilir. Klempin dişe yerleştirilme işleminden sonra lastik örtü çerçeveye takılır. Lastik örtü klempin üzerinden geçirilir ve bu işlem sırasında klempin hareket etmemesine dikkat edilir (Resim 12A, B, C). 


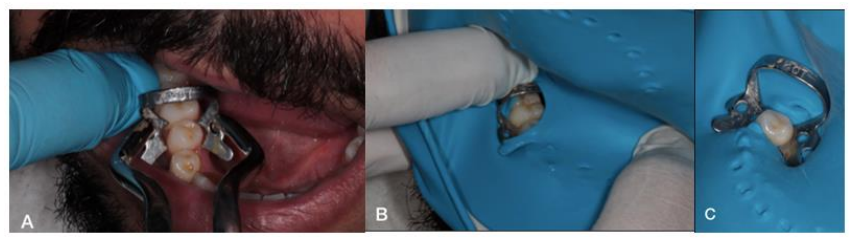

Resim 12

A. Klempin dişe uygulanması. B. Lastik örtü ve çerçevenin yerleştirilmesi. C. Klempin ve lastik örtünün kontrolü.

\section{Yöntem}

$\mathrm{Bu}$ yöntem 2. yöntemin uygulanabildiği fakat lastik örtünün klemp üzerinden gerilmesinin daha uygun olduğu durumlarda kullanılır. Klemp lastik örtüye boyun bölümünden tutturulur. $\mathrm{Bu}$ sayede klempin delikleri lastik örtünün altında kalır (Resim13A). Lastik örtü forseps tutmayan diğer el ile toplanır ve klemp dişe yerleştirilir (Resim 13B). Sonrasında lastik örtü klemp üzerinden dikkatli bir şekilde gerdirilerek atlatıtır ve lastik örtü çerçeveye geçirilir.(Resim 13C, D).
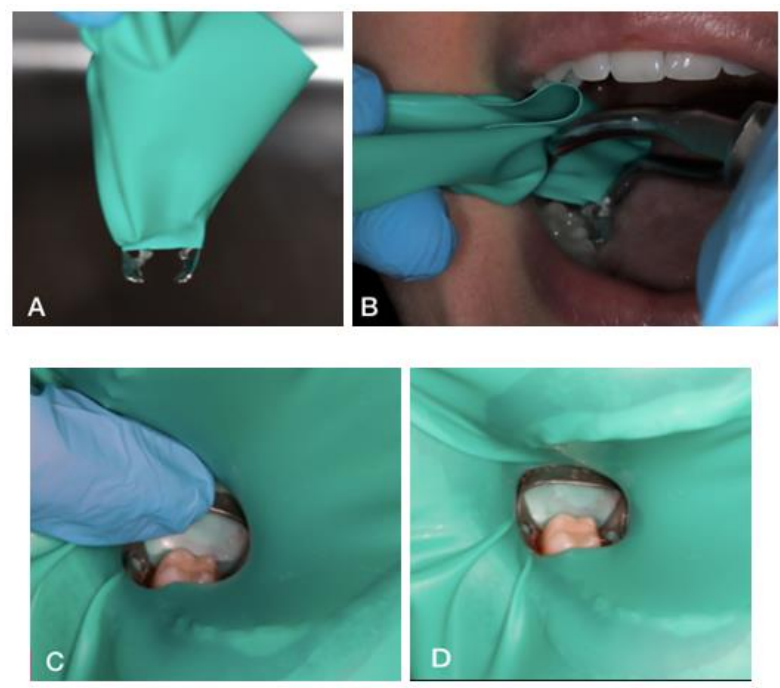

Resim 13

A. Klempin boyun bölgesinin lastik örtü içinde kalacak şekilde tutturulması. B. Klempin dişe yerleştirilmesi. C. Lastik örtünün yerleştirilmesi. D. Klempin ve lastik örtünün kontrolü.

\section{Yöntem}

Lastik örtü ve çerçeve yerleştirildikten sonra klempin dişe yerleştirildiği yöntemdir. Delik dişin ve dişetinin üzerinde gerildiğinde daha iyi bir görüş alanı oluşturur ve ardından forseps yardımıyla klemp yerleştirilir (Resim 14A,B,C).
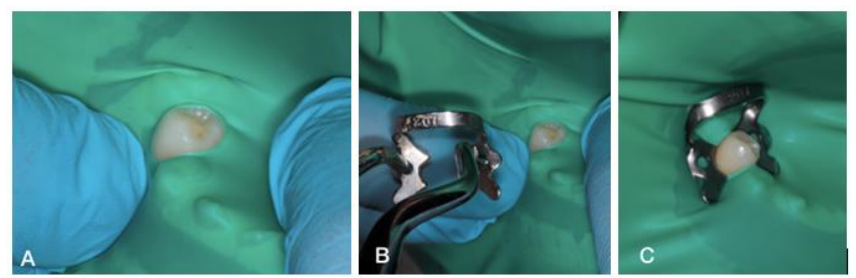

Resim 14

A. Lastik örtü ve çerçevenin yerleştirilmesi. B. Klempin uygulanması. C. Klemnin ve lastik örtünün kontrolü.

\section{Dişin Dezenfeksiyonu}

Lastik örtü diş üzerine yerleştirildikten sonra kronlar ve onları çevreleyen bölümler \%1.5' luk klorheksidin, $\% 70$ ' lik izopropil alkol gibi solüsyonlar diş veya dişleri dezenfekte etmek için kullanılabilir. ${ }^{21}$ Ayrıca koronavirüs oksidasyona duyarlı olduğundan işlem öncesinde 1 dakika süreyle $\% 1$ hidrojen peroksit veya $\% 0.2$ povidin iyot gibi oksidatif ajanlar kullanılabilir. ${ }^{27}$

\section{Lastik Örtünün Uzaklaştıııması}

Klempin forseps yardımıyla çıkarımasıyla kolaylıkla uzaklaştırılabilir. Dişin ara yüzeylerinde bulunan lastik örtü çekilerek veya ufak makaslar yardımıyla kesilerek çıkartılabilir. Lastik örtü uzaklaştırıldıktan sonra ağız içerisi dikkatli bir şekilde incelenmelidir.

\section{Lastik Örtünün Takılamadığı Durumlar}

Lastik örtü; klostrofobisi olan hastalarda, astım hastalarında, epilepsi hastalarında, ağız solunumu yapan hastalarda ve şiddetli çapraşıklığı olan hastalarda kullanılması kontrendikedir. ${ }^{13,21,24}$ Çapraşıkığı bulunan vakalarda da kullanımı birkaç diş izolasyonu ile birlikte uygun olabilir.

\section{SONUÇ}

Kök kanal tedavisi ve adeziv diş hekimliğinde başarı sağlanabilmesi için çalışma alanının izolasyonu ön koşuldur. Rubber dam; özellikle damlacık yoluyla bulaşan başta koronavirus gibi enfeksiyonlara karşı koruma sağlar ve bu enfeksiyöz hastalıkların bulaşmasını ve yayılımını engeller, hastalara rahat, konforlu ve daha güvenilir bir tedavi seçeneği sunar. Ayrıca günümüzde artan malpraktis davalarına karşı hekimi koruduğu için önemi gittikçe artan bir izolasyon yöntemidir. 


\section{KAYNAKLAR}

1. Heling B, Heling I. Endodontic procedures must never be performed without the rubber dam. Oral Surg Oral Med Oral Pathol Oral Radiol Endod 1977;43:464-6.

2. Reid JS, Callis PD, Patterson CJ. Rubber dam in clinical practice. London: Quintessence Publishing, 1991.

3. Holliday R. Cohen's Pathways of the Pulp, 11th edn. St. Louis: Elsevier, 2011.

4. Ahmed $\mathrm{H}$, Cohen S, Lévy $\mathrm{G}$, Steier L, Bukiet $\mathrm{F}$. Rubber dam application in endodontic practice: an update on critical educational and ethical dilemmas. Aust Dent J 2014;59:457-63.

5. Anabtawi MF, Gilbert GH, Bauer MR, Reams G, Makhija SK, Benjamin PL, et al. Rubber dam use during root canal treatment: findings from the dental practice-based research network. J Am Dent Assoc 2013;144:179-86.

6. Roberson TM HO, Swift EJ. Operatif Diş Hekimliğinde Göz Önüne Alınması Gereken Hazırlık Aşamaları. Gürgan S, editör. Art and Science of Operative Dentistry. Güneş Tıp Kitabevleri; 2011. p. 463-492

7. Chandra SCS, Chandra G. Isolation of the operating field. Textbook of Operative Dentistry. Jaypee Brothers Medical Publishers; 2007. p.112-120.

8. Cochran MA, Miller $\mathrm{CH}$, Sheldrake MA. The efficacy of the rubber dam as a barrier to the spread of microorganisms during dental treatment. J Am Dent Assoc 1989;119:141-4.

9. Carrotte PV. Current practice in endodontics: 4. A review of techniques for canal preparation. Dent Update 2000;27:488-93.

10.Sjögren U, Hägglund B, Sundqvist G, Wing K. Factors affecting the long-term results of endodontic treatment. J Endod 1990;16:498-504.

11.Lynch C, O'Byrne M, McConnell R, Neville K. Opinions of Irish dental practitioners on dental nurse training. J Ir Dent Assoc 2003;49:90-4.

12. Cohen S, Schwartz S. Endodontics and the law. J Can Dent Assoc 1985;13:97-100.

13.Aşçı SK. Endodonti, 1.baskı. İstanbul: Quintessence Yayıncılık,2014.

14.European Society of Endodontology. Consensus report of the European Society of Endodontology on quality guidelines for endodontic treatment. Int Endod J 1994;27:115-24.

15. Christensen GJ. Using rubber dams to boost quality, quantity of restorative services. J Am Dent Assoc 1994;125:81-2.

16. Hülsmann M, Schafer E. İşlem Öncesi Restorasyon ve Lastik Örtünün Yerleştirilmesi. Şen $\mathrm{BH}$, editor. Endodontide Problemler Etiyoloji, Tanı ve Tedavi. Quintessence Yayıncılık; 2014. p. 95-107.

17. Barnum S. History of the discovery of the dam. Can J Dent Sci. 1877;4:88-9.
18.Winkler R. Sanford Christie Barnum - inventor of the rubber dam. Quintessenz 1991;42:483-6.

19. Haug SR, Solfjeld AF, Ranheim LE, Bårdsen A. Impact of case difficulty on endodontic mishaps in an undergraduate student clinic. $J$ Endod 2018;44:1088-95.

20. Imbery TA, Carrico CK. Dental dam utilization by dentists in an intramural faculty practice. J Clin Exp Dent 2019;5:365-76.

21.Alaçam T. Endodonti, 1. Baskı. Ankara: Özyurt Matbaacılık,2012.

22. Baum L PR, Lund MR. Isolation of the working field. Textbook of Operative Dentistry. WB Saunders; 1985. p. 172-203.

23. Kunzelmann KH, Wilson NHF, Fuzzi M. Operatif Dişhekimliğinde Gelişmeler Güncel Pratik Uygulamalar. Aykor A, Tanalp J, editors. Quintessence Yayıncılık; 2006. p. 35-48.

24. Çalışkan MK. Endodontide Tanı ve Tedaviler, 1.baskı. İstanbul: Nobel Matbaacılık,2006.

25. https://aseptico.com/store/rubber-damaccessories/rubber-dam-clamps/00-rubber-damclamps/

26.Sposetti VJ. Topical anesthetic gel as a rubber dam lubricant. J Prosthet Dent. 1985;53(2):291.

27.Peng X, Xu X, Li Y, Cheng L, Zhou X, Ren B. Transmission routes of 2019-nCoV and controls in dental practice. Int J Oral Sci. 2020;12(1):1-6.

Yazışma Adresi:

Mehmet ESKIBAĞLAR

Fırat Üniversitesi

Diş Hekimliği Fakültesi

Endodonti AD,

Elazığ, Türkiye

Tel : +905541679323

E-mail : eskibaglarmehmet@hotmail.com 